\title{
Evaluating the Performance of Albanian Savings and Credit (ASC) Union
}

\author{
Jonida Bou Dib (Lekocaj) ${ }^{1^{*}}$, Eralda Shore ${ }^{*}$ and Mariana Nikolla ${ }^{2 *}$
}

\begin{abstract}
:
This research paper aimed to evaluate the role of ASC Union through three main poles: its performance in relation to outreach, its financial sustainability, and its welfare impact. It was based mainly on a descriptive study and focused on an accurate event, trying to answer questions such as: what, where, how, who and when, through the use of different information and already existing theories. Moreover, a triangulated methodology combining interviews, questionnaires and observations was applied in order to analyze the microcredit impacts.

From the outreach angle, it was found that ASC Union's outreach has shown an increment over the period of study with different rates of growth from 2003 to 2010 on average by $14.7 \%$. On the other hand, the operational sustainability measured by return on assets and return on equity showed instability over the period of the study, making the ASC Union financial sustainability doubtful. In summary, the members confirmed that ASC Union helped them to improve their activities and income, where 87 out of 100 farmers confirmed that their income increased in the last 3 years, while 31 farmers out of 100 , respectively 8,9 and 10 year-old-members, proclaimed that using the micro-loan helped them to expand their activities, while 56 farmers confirmed that microcredit helped them not only in improving their income and activity, but also their production increment and activity expansion.
\end{abstract}

Key words: Microfinance, Outreach, Financial Sustainability, Impact, Albania

\section{Introduction}

If we are looking for one single action which will enable the poor to overcome their poverty, I would go for credit. Money is power (Yunus, 1994).

Robinson (2001) emphasized that about $90 \%$ of the people in developing countries lack access to financial services from institutions, either for credit or for savings and although there are some 3000 microfinance institutions serving more than 100 million clients around the world, it must be noted that the ittp://www.gdrc.org/icm/grameen-keynote.html

\footnotetext{
${ }^{1}$ The Economy and Agricultural Policies Department

${ }^{2}$ Mathematics and Computer Science Department

* Agricultural University of Tirana, Koder Kamez, Albania
} 
problem of financing agriculture is still very acute. Between $60-99 \%$ of rural households in developing countries earn a living from farming, even if it is rarely the only source of income for households. Establishing financial services in out-of-the-way areas with low population density, which lack basic infrastructure (roads, electricity, health centers, and the like), is truly a challenge. ${ }^{1}$

"By living up to the credit contract, poor people discover their own capacity to direct their future". ${ }^{2}$ Khandker (1998) defines microcredit as the extension of small amounts of collateral-free institutional loans by $\mathrm{MFI}^{3}$ s to poor people, the unemployed or poor entrepreneurs, and farmers for their self-employment and income generation. Microfinance holds a big promise to generate income and employment and alleviate poverty in developing countries. Thus, without exaggerating, it can be stated that microfinance has improved the lives of millions of people by fighting social exclusion and stimulating small enterprise development. It seems that we are a witness of the long-awaited marriage between "doing well" and "doing good".

There are different arguments concerning how to evaluate the performance of microfinance institutions. Kereta (2007), cited by Zeller and Meyer (2002), indicated that there is what is called a "Critical Micro-finance Triangle" that needs to be looked at to evaluate MFIs based on their objective. They went further to point out that this microfinance triangle is the main policy objective of these MFIs which are aimed towards development. The performance of the financial sector in providing financial intermediation for the targeted people can be evaluated in three vital dimensions: financial sustainability, outreach, and welfare impact.

From various initiatives that have been carried out in different contexts, this research discusses the question about the role of MFIs in rural Albania seen and explained from the point of view of rural Albania and Albanian Savings and Credit (ASC) Union performance.

\subsection{Statement of the problem}

Albania has valuable natural resources for a strong agricultural sector. The expansion and well functioning of farms and other agricultural activities, require more than natural resources, but the unpredictable challenges that MFIs face in delivering their microcredit programs, make the opportunities to be seen from far away. This study deals with the theme of microfinance and in particular attention is given to the performance of the Albanian Saving and Credit (ASC) Union, and its role in financing farm development. ASC Union has for many

\footnotetext{
${ }^{1}$ http://www.fondation-farm.org/spip.php?page=article\&id_article=230

${ }^{2}$ http://www.responsability.com/domains/responsability ch/data/free docs/rADiscussionPap er2-ThesocialimpactofmicrofinanceandhowtomeasureitEN.pdf

${ }^{3}$ Microfinance Institutions
} 
years aimed to support Albania's farmers with micro-financing, but it is unclear whether their administrative practices support their efforts or create additional hurdles for farmers in need of financing for the development of their activities.

\subsection{Significance of the study}

In trying to justify why the current study is important, it is vital to mention that this area of study has great value in the development of the socio-economic activities in developing countries and their contributions to the development of agriculture and especially farmers' activities in Albania. Extensive research has been carried out on the role of the financial management aspects. This research will therefore focus on ASC Union which has been exploited in terms of its performance in developing the rural areas. A study of this nature is equally very important because it is going to enlighten us on the role that ASC Union is playing in the rural sector since it is in partnership with some international MFIs and with the Albanian government.

\section{Methodology}

This research is an exploratory study that investigates the performance of the ASC Union based on its financial sustainability, its outreach and the welfare impacts on the farmer's activities and life through the use of different sources, information and already existing theories. Furthermore, we used a triangulated methodology by combining interviews, questionnaires and observations in order to analyze the welfare impacts while the empirical part of our research was mainly based on a single case study of ASC Union.

Secondary data sources are the foundation for which the theoretical framework is built. ASC Union was visited for financial data and statistical reports on microfinance products and services. Moreover, 100 questionnaires were conducted in some branches of the ASC Union in eight villages in the Tirana' region: Zall-Herr, Pinar, Vore, Marikaj, Preze, Babrru, Petrele, Mullet and Dobresh, and in the Shkodra' region: Tarabosh and Drini Dy. Respectively farmers between 3 to 10 year-old members were surveyed and the actual response was 97 for Tirana and constituted 89 males and 8 females. In Shkoder, a total of 3 questionnaires were personally distributed and filled by 3 male farmers.

Concerning the data analysis method, tabling and the graphic processing method have been used for the comparison of different data and for presenting the progress of results over time. A statistical method like the SPSS software program for analyzing and comparing various aspects with the main purpose to show the level of involvement of the farmers in the microcredit program of the 
ASC Union and econometric tools such as regression analysis were used to address the issues of impacts.

\section{Results}

Outreach: The number of active clients of ASC Union in Albania (Figure 1 below), has shown an increment over the study period with different rates of growth leading the ASC Union outreach to rise from 7,621 active clients in 2003 to 18,994 active clients in 2010 , with an average by $14.7 \%$. On the other hand, the average loan size has shown a growth for the period 2005-2008 by reaching the amount of $\$$ US 2,509 . As we can see from the graph the loan size decreased at \$US 2,207 in 2010. Some regard an average outstanding loan balance below $20 \%$ of per capita GNI or \$US 150 as a rough indication that clients are very poor, but the graph below shows that the average outstanding loan stays between \$US 1,500 and \$US 2,200. Those numbers give the right indications that ASC Union' targeted group are the low-income people and it does not reach the very poor people; this result fits very well with the policy applied by the credit union. Average outstanding balance is roughly related to client poverty, because better off clients tend to be uninterested in smaller loans or deposit accounts and as we can see from this graph in the last 2 years more the number of active clients raise, more the average outstanding balance and the supply for microloan decrease. Moreover, in this kind of situation, exists the risk that the union to lose its clients, because if they will have higher income, they can go and apply to other financial institutions (Rosenberg, 2009).

Figure 1: ASC Union's outreach (Albania)



Source: http://www.mixmarket.org/mfi/country/Albania and ASC Union' Financial Statements 
A retail lender's ability to collect loans is critical for its success: if delinquency is not kept to very low levels, it can quickly spin out of control (Rosenberg, 2009).

As it can be seen from Figure 2 below $\mathrm{PAR}^{4}>30$ days decreased from $0.5 \%$ in 2005 to $0.01 \%$ in 2007 , and then it increased from 2007 to 2010 by reaching $4.81 \%$. The same situation happened with the write-off ratio. It has shown an increment from 2007 to 2010 by reaching the value of $0.77 \%$. From the data shown in the graph below, PAR does not exceed 5\%, a fact that makes ASC Union sustainable by having PAR under control.

Figure 2: ASC Union's portfolio quality (Albania)

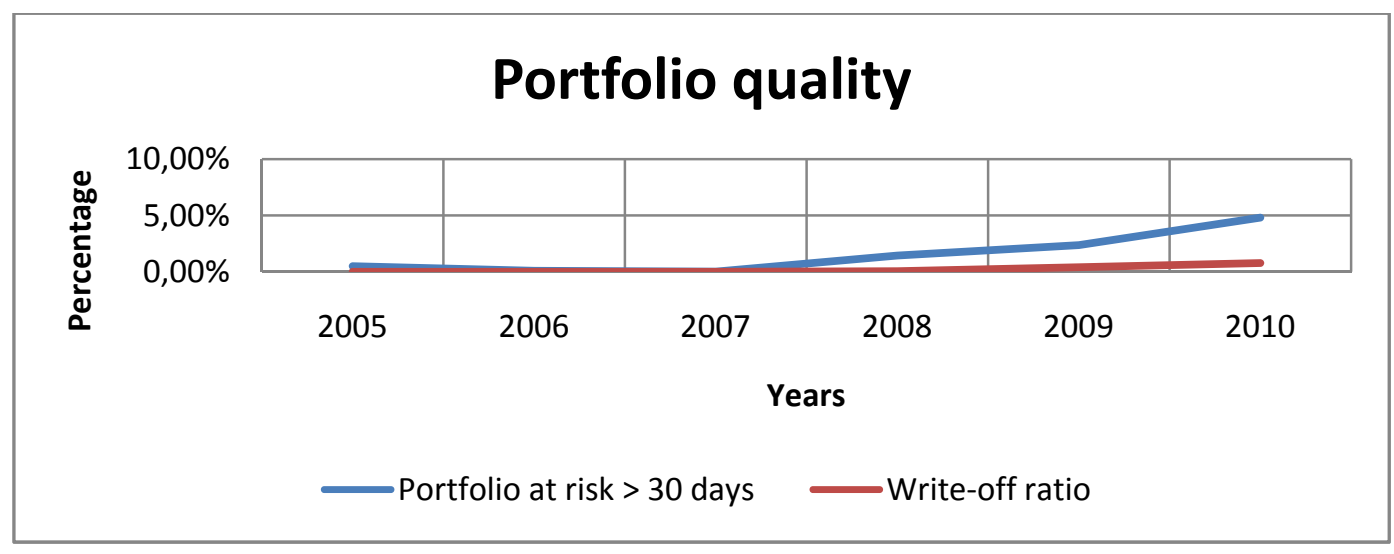

Source: MIX Market

Financial Sustainability: Concerning the financial sustainability, indicators such as ROA (return on assets) and ROE (return on equity) have shown instability over the period of the study. What is clearly mentioned in the graph below is the financial non-sustainability of the ASC Union, especially from 2008 to 2009 where the ROA and ROE decreased respectively at the values $2.34 \%$ and $8.89 \%$ respectively. Those facts indentify that ASC Union' profit performance is not making any improvement over time.

\footnotetext{
${ }^{4}$ Portfolio at Risk
} 
Figure 3: The ASC Union' financial sustainability (Albania)

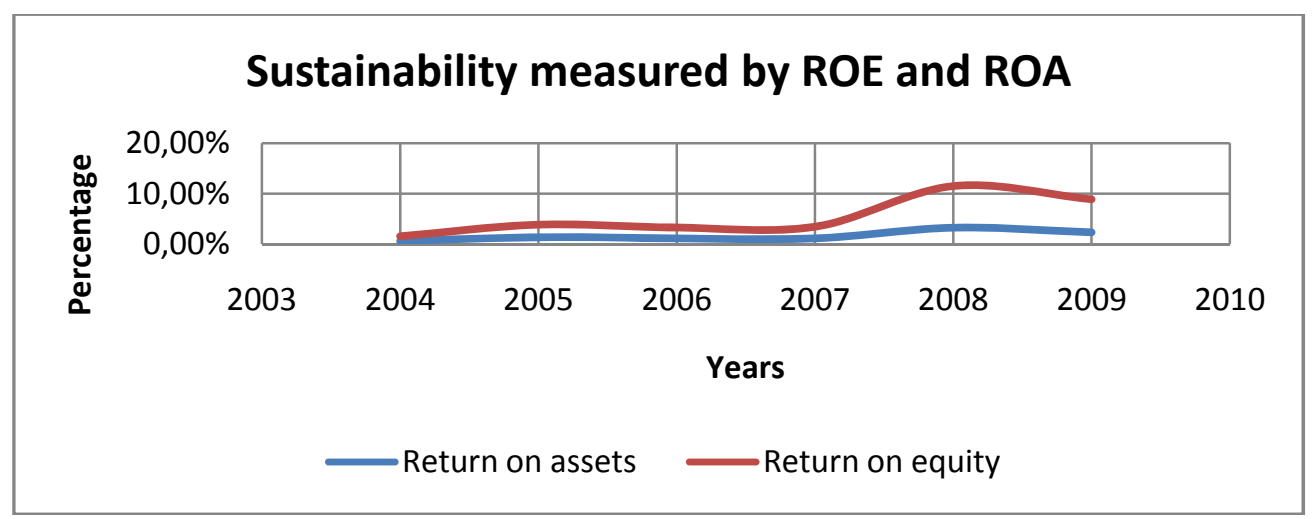

Source: MIX Market

Figure 4: Sustainability vs. outreach

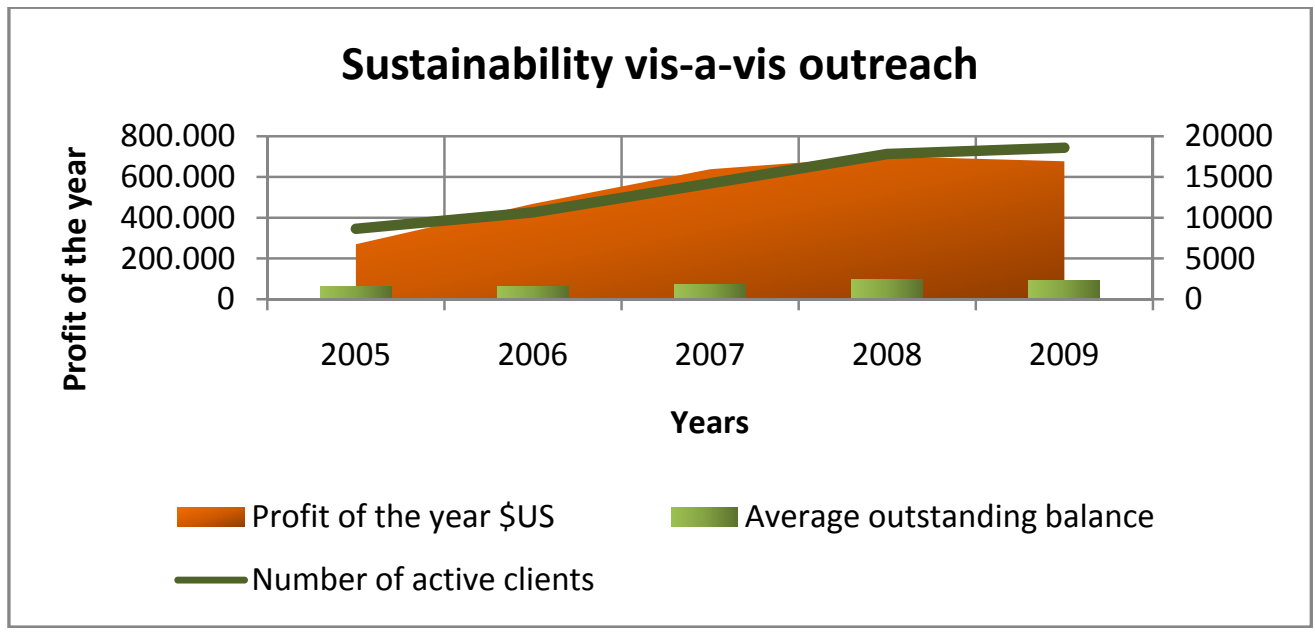

Source: MIX Market

According to Figure 4 above, the profit and the average outstanding loan have decreased for the period 2008-2009, where the number of active clients has shown only an increment for each year. What comes to our mind is that although the number of clients is rising, the credit union is risking its sustainability, because as we can see from Figure 4, the average outstanding loan is not able to cover the needs of the clients for micro-loans and this can bring high costs in the future, threatening the sustainability of ASC Union, which, as is shown from above, is not presenting a good performance in the last years. 
Welfare impacts: To analyze the influence of microcredit on the farmers and to finalize its impacts on their activities and lives, a cross-tabulation between the number of years of membership and the benefits from the micro-loan was created. Looking at the last 3 columns in Table 1, it is clear that 31 farmers out of 100 , respectively 8,9 and 10 year-old-members, proclaim that using the micro-loan helped them to expand their activities, while 56 farmers confirmed that microcredit helped them not only in improving their income and activity, but also their production increment and activity expansion.

Table 1: Cross-tabulation between the benefits of micro-loan * \# of years as a member of ASC Union

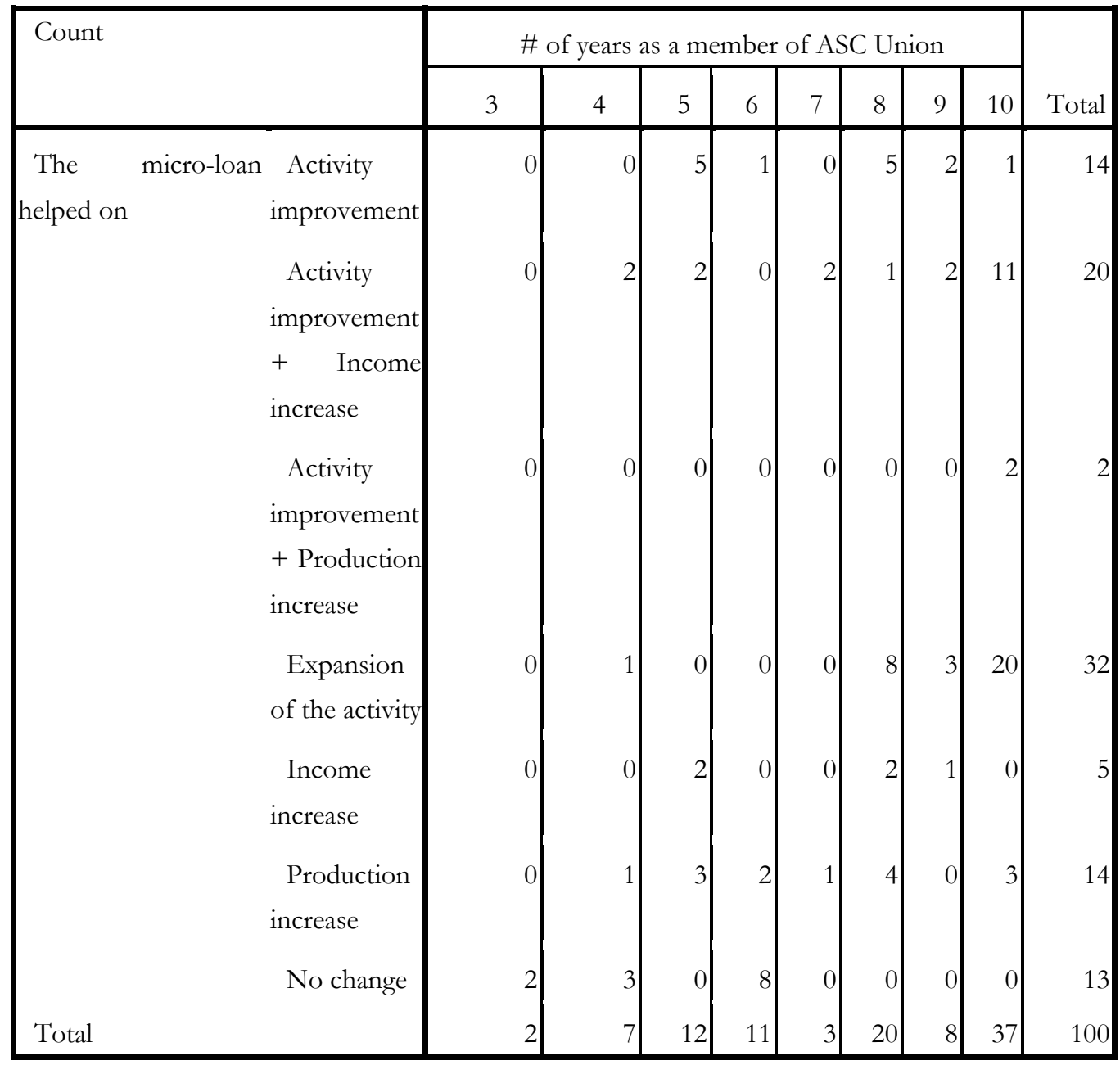


As can be seen by the cross-tabulation in Table 2 below, 87 farmers out of 100 , who are 4 to 10 year-old-members of the credit union, confirmed that their income increased in the last 3 years, whereas only 13 farmers who are in their third, fourth and sixth year of membership answered that there was no change in their income in those 3 years.

Table 2: Cross-tabulation between the \# of years as a member of ASC Union * Changes in income in the last 3 years

\begin{tabular}{|c|c|c|c|c|}
\hline \multirow{2}{*}{\multicolumn{2}{|c|}{ Count }} & \multicolumn{2}{|c|}{$\begin{array}{l}\text { Changes in income } \\
\text { in the last } 3 \text { years }\end{array}$} & \multirow[b]{2}{*}{ Total } \\
\hline & & Increase & $\begin{array}{c}\text { No } \\
\text { change }\end{array}$ & \\
\hline \multirow{8}{*}{\multicolumn{2}{|c|}{$\begin{array}{ll}\text { \# of years as a member } & 3 \\
\text { of ASC Union } & 4 \\
& 5 \\
6 \\
7 \\
8 \\
9 \\
10\end{array}$}} & & 2 & 2 \\
\hline & & 4 & 3 & 7 \\
\hline & & 12 & 0 & 12 \\
\hline & & 3 & 8 & 11 \\
\hline & & 3 & 0 & 3 \\
\hline & & 20 & 0 & 20 \\
\hline & & 8 & 0 & \\
\hline & & 37 & 0 & 37 \\
\hline Total & & 87 & 13 & 100 \\
\hline
\end{tabular}

From the bar chart below (Figure 5), the highest level of the microcredit impact is expressed through the activity expansion and confirmed from the 8, 9 and 10 year old members.

Also what is prominent from this graph is the large number of members from 3 to 10 year old, who proclaim that microcredit helped in improving their activities and increasing their income, while on the other hand members since 3, 4 and 6 years admit that there is no change in their activities, income or life. 


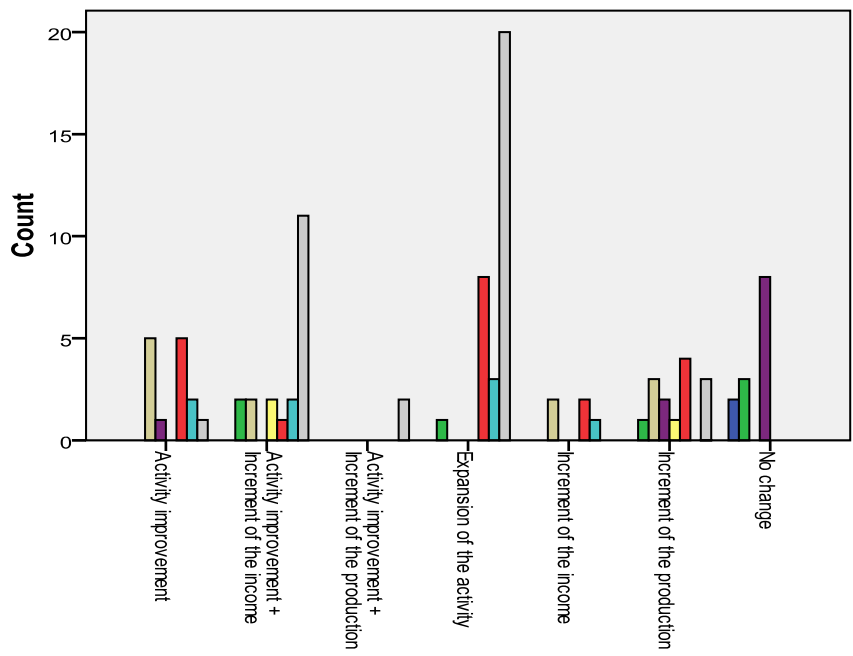

\# of years as a

member of ASC

Union

吕 3

$\square 4$

号 6

$\square^{\circ} 9$

Figure 5: Impacts of microcredit during the years of membership

\section{Conclusions}

From the outreach angle, it was found that ASC Union's outreach has shown an increment over the period of study with different rates of growth, leading the industry's outreach to rise in the period from 2003 to 2010 on average by $14.7 \%$. On the other hand, it was identified that the average outstanding loan stays between \$US 1,500 and \$US 2,200 and the client poverty level expressed in percentage does not go below 50\% (2006-2009). Moreover, from a financial sustainability angle, we discovered that ASC Union in rural Albania is doubtful. The financial sustainability measured by return on assets and return on equity has shown instability over the period of the study, showing that the credit union's profit performance is not making any improvement over time. To continue, a positive correlation among the loan size, outreach and profit was observed, implying that the credit union can reach more clients to attain its social mission. On the other hand the credit union was risking its sustainability, because the average outstanding loan was not able to cover the needs of the clients for micro-loans and this can bring high costs in the future, threatening the sustainability of ASC Union, which was not presenting a good performance in the last years. Overall, if we can describe the role of ASC Union in supporting and financing the farmers from the welfare impact angle, we can determine it as efficient and hopeful where 87 out of 100 farmers who are members since 4 to 10 years, confirmed that their income increased in the last 3 years, while only 13 farmers admitted that there is no change in their income for the last 3 years as a 
member of the ASC Union. Furthermore, 31 farmers out of 100, respectively 8, 9 and 10 year-old-members, proclaim that using the micro-loan helped them to expand their activities, while 56 farmers confirmed that microcredit helped them not only in improving their income and activity, but also their production increment and activity expansion.

\section{References}

Albanian Saving and Credit Union, Annual Reports 2006, 2007, 2008 and 2009.

Khandker, Shahidur R., (1998): Fighting Poverty with Microcredit: Experience in Bangladesh. New York, Oxford University Press.

Kereta, B.B., (2007): Outreach and Financial Performance Analysis of Microfinance Institutions in Ethiopia. African Economic Conference, United Nations Conference Center, (UNCC), Addis Ababa, Ethiopia, pp 8-22.

Robinson, S. M.( 2001): The Microfinance Revolution: Sustainable Finance for the Poor, Washington, D.C. World Bank Publication, Vol.1, New York.

Rosenberg, R., (2009): Measuring Results of Microfinance Institutions: Minimum Indicators that Donors and Investors Should Track. CGAP Publishing, June, pp 3-13, 17-19.

http://www.fondation-farm.org/spip.php?article230\#cadrage (last access 2.12.2010) http://www.gdrc.org/icm/grameen-keynote.html http://www.mixmarket.org/mfi/asc-union/data (last access 15.04.2011) http://www.mixmarket.org/mfi/country/Albania (last access 22.03.2011) http://www.responsability.com/domains/responsability_ch/data/free_docs/ ADiscussionPaper2-ThesocialimpactofmicrofinanceandhowtomeasureitEN.pdf (last access 10.02.2010. 